\title{
UNIVERSITYOF BIRMINGHAM

\section{Leveling up? An inter-neighborhood experiment on parochialism and the efficiency of multi-level public goods provision}

\author{
Gallier, Carlo; Goeschl, Timo; Kesternich, Martin ; Lohse, Johannes; Reif, Christiane; \\ Roemer, Daniel
}

DOI:

10.1016/j.jebo.2019.05.028

License:

Creative Commons: Attribution-NonCommercial-NoDerivs (CC BY-NC-ND)

Document Version

Peer reviewed version

Citation for published version (Harvard):

Gallier, C, Goeschl, T, Kesternich, M, Lohse, J, Reif, C \& Roemer, D 2019, 'Leveling up? An inter-neighborhood experiment on parochialism and the efficiency of multi-level public goods provision', Journal of Economic Behavior \& Organization, vol. 164, pp. 500-517. https://doi.org/10.1016/j.jebo.2019.05.028

Link to publication on Research at Birmingham portal

Unless a licence is specified above, all rights (including copyright and moral rights) in this document are retained by the authors and/or the copyright holders. The express permission of the copyright holder must be obtained for any use of this material other than for purposes permitted by law.

-Users may freely distribute the URL that is used to identify this publication.

- Users may download and/or print one copy of the publication from the University of Birmingham research portal for the purpose of private study or non-commercial research.

- User may use extracts from the document in line with the concept of 'fair dealing' under the Copyright, Designs and Patents Act 1988 (?)

- Users may not further distribute the material nor use it for the purposes of commercial gain.

Where a licence is displayed above, please note the terms and conditions of the licence govern your use of this document.

When citing, please reference the published version.

Take down policy

While the University of Birmingham exercises care and attention in making items available there are rare occasions when an item has been uploaded in error or has been deemed to be commercially or otherwise sensitive.

If you believe that this is the case for this document, please contact UBIRA@lists.bham.ac.uk providing details and we will remove access to the work immediately and investigate.
} 


\section{LEVELING UP?}

AN INTER-NEIGHBORHOOD EXPERIMENT ON PAROCHIALISM AND THE EFFICIENCY OF MULTI-LEVEL PUBLIC GOODS PROVISION

\section{Supplementary Material}
A: Experimental Procedure
B: Experimental Instructions
C: Power Calculations 
Supplementary Material A: Experimental Procedure

Figure S.1: Schematic diagram experimental procedures

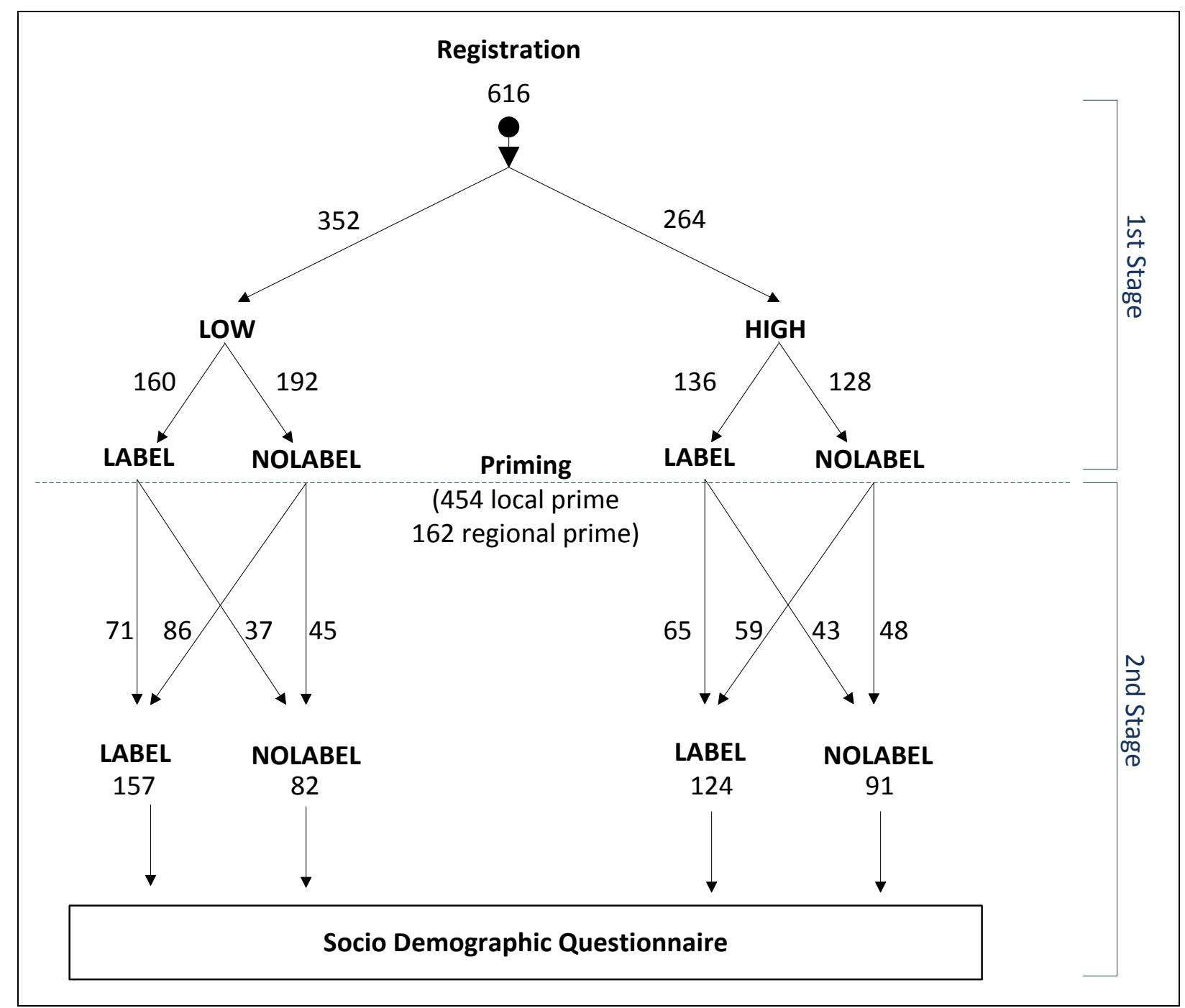




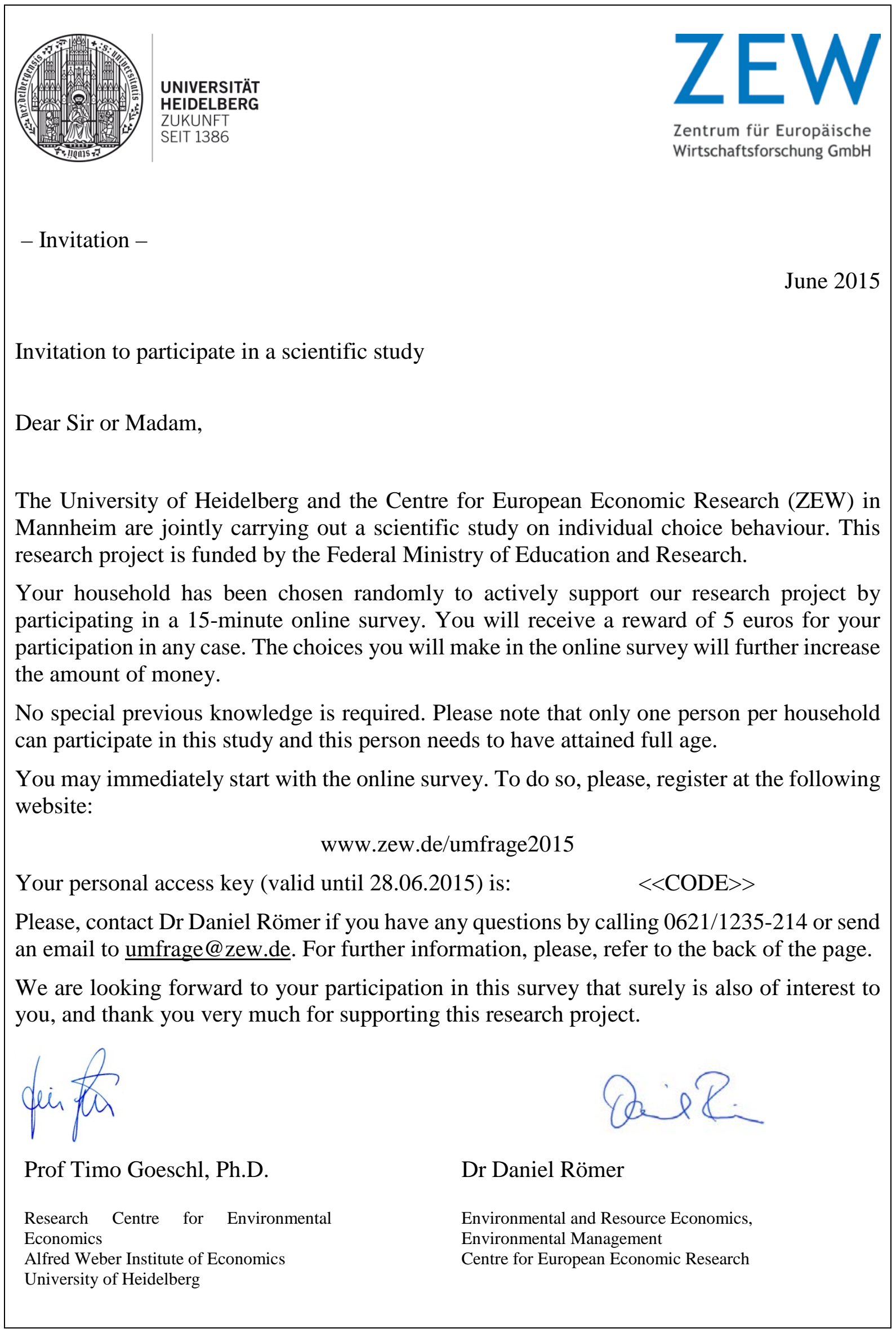


Information sheet on content and procedure of the study

Who is organising this study?

This study is part of a joint research project of the University of Heidelberg and the Centre for European Economic Research (ZEW) in Mannheim. The University of Heidelberg is a public institute for education and research of the federal state Baden-Wuerttemberg. The ZEW is a non-profit research institute and member of the Leibniz Association. This research project is funded by the Federal Ministry of Education and Research.

How can I participate?

You may participate starting from today until at the latest 28.06.2015 (as long as the maximum number of participants has not been reached). You only need a device (e.g. computer, laptop, tablet or smartphone) with internet access and internet browser (e.g. Internet Explorer, Firefox, Safari, Chrome).

- Computer/laptop: To register, please, enter www.zew.de/umfrage2015 into the address bar of your internet browser. It leads you to the start screen where you need to enter your personal access key. The access key is on the first page of the invitation letter. This access key allows you to participate in the study one time only. The online survey starts immediately after you have entered the key.

- Tablet/smartphone: To register, please, enter www.zew.de/umfrage2015 into the address bar of your internet browser. Alternatively, you may also use an adequate app to read the QR code beside this paragraph. Both options lead you to the start screen where you need to enter your personal access key. The access key is on the first page of the invitation letter. This access key allows you to participate in the study one time only. The online survey starts immediately after you have entered the key.

What about my data?

The information you give is exclusively used for research purposes and analysed anonymously. Your personal data are exclusively used to transfer your reward to you and are neither related to the information given in the survey nor given to any third-party.

What influences the amount of reward I will receive?

Your reward consists of a standard reward and an additional reward. In any case, you will receive the standard reward of 5 euros for participating. The amount of the additional reward depends on your own choices and those of the other participants.

How will I receive my reward?

We want to transfer your reward to you without you having to give us your bank data. Therefore, you will receive a shopping voucher by mail about 4 weeks after participating. The value of the voucher equals the total amount of your reward (standard reward of 5 euros plus additional reward). You may use the voucher in many different local stores and online shops to pay for your shopping (e. g. Galeria Kaufhof, Karstadt, Media Markt, Saturn - for the complete list of stores accepting the voucher, please, refer to this website: http://www.edenred.de/produkte/ticket-shopping-card/akzeptanzpartner.html) 


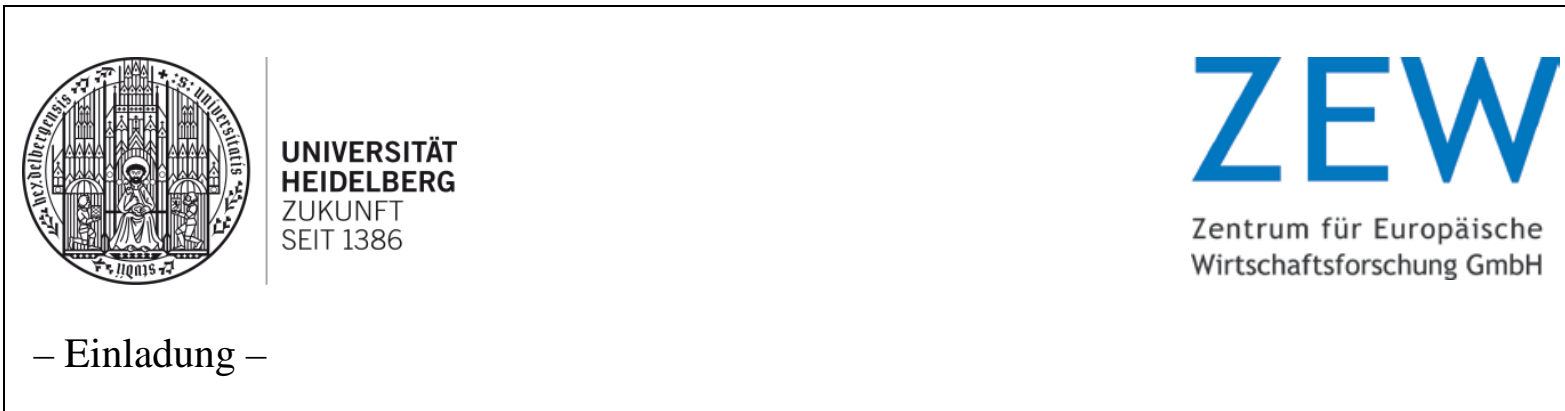

Juni 2015

Einladung zur Teilnahme an einer wissenschaftlichen Studie

Sehr geehrte Damen und Herren,

die Ruprecht-Karls-Universität Heidelberg führt gemeinsam mit dem Zentrum für Europäische Wirtschaftsforschung (ZEW) in Mannheim eine wissenschaftliche Studie zu individuellem Entscheidungsverhalten durch. Das Forschungsvorhaben wird durch das Bundesministerium für Bildung und Forschung gefördert.

Ihr Haushalt wurde zufällig ausgewählt, unser Forschungsvorhaben durch Ihre Teilnahme an einer 15-minütigen Onlinebefragung aktiv zu unterstützen. Für Ihre Teilnahme erhalten Sie in jedem Fall eine Teilnahmevergütung im Wert von mindestens 5 Euro. Ihre Entscheidungen im Rahmen der Onlinebefragung werden diesen Betrag weiter erhöhen.

Es sind keine besonderen Vorkenntnisse erforderlich. Bitte beachten Sie, dass nur eine Person pro Haushalt an der Studie teilnehmen kann und dass diese Person volljährig sein muss.

Sie können sofort mit der Teilnahme beginnen. Dazu melden Sie sich bitte auf der folgenden Internetseite an:

$$
\text { www.zew.de/umfrage2015 }
$$

Ihr persönlicher Zugangsschlüssel (gültig bis zum 28.06.2015) lautet: $\quad<<$ CODE $>>$

Für Rückfragen steht Ihnen Dr. Daniel Römer unter der Telefonnummer 0621/1235-214 oder per E-Mail unter umfrage@zew.de gerne zur Verfügung. Weitere Informationen finden Sie auf der Rückseite.

Wir freuen uns auf Ihre Teilnahme an dieser sicherlich auch für Sie interessanten Befragung und danken Ihnen herzlich für die Unterstützung unseres Forschungsprojektes.

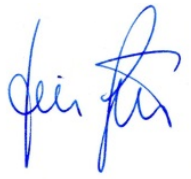

Prof Timo Goeschl, Ph.D.

Forschungszentrum für Umweltökonomik

Alfred-Weber-Institut für

Wirtschaftswissenschaften

Ruprecht-Karls-Universität Heidelberg

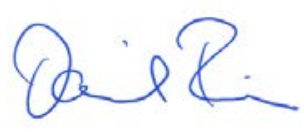

Dr. Daniel Römer

Umwelt- und Ressourcenökonomik,

Umweltmanagement

Zentrum für Europäische

Wirtschaftsforschung 


\section{Informationsblatt zu Inhalt und Ablauf der Studie}

Wer steht hinter der Studie?

Die Studie ist Teil eines gemeinsamen Forschungsvorhabens der Ruprecht-Karls-Universität in Heidelberg und des Zentrum für Europäische Wirtschaftsforschung (ZEW) in Mannheim. Die Universität Heidelberg ist eine öffentliche Lehr- und Forschungseinrichtung des Landes Baden-Württemberg. Das ZEW ist ein gemeinnütziges Forschungsinstitut und Mitglied der Leibniz Wissenschaftsgemeinschaft. Finanziert wird das Forschungsvorhaben vom Bundesministerium für Bildung und Forschung.

Wie kann ich teilnehmen?

Sie können ab sofort bis spätestens 28.06.2015 teilnehmen (solange die maximale Teilnehmerzahl noch nicht erreicht ist). Sie benötigen dazu lediglich ein Gerät (z.B. Computer, Laptop, Tablet oder Smartphone) mit Internetanschluss und Internetbrowser (z.B. Internet Explorer, Firefox, Safari, Chrome).

- $\quad$ Computer/Laptop: Um sich anzumelden, geben Sie www.zew.de/umfrage2015 in die Adresszeile Ihres Internetbrowsers ein. So gelangen Sie auf den Startbildschirm. Auf diesem geben Sie Ihren persönlichen Zugangsschlüssel ein. Den Zugangsschlüssel entnehmen Sie bitte der ersten Seite des Einladungsschreibens. Dieser Zugangsschlüssel ermöglicht Ihnen eine einmalige Teilnahme. Ihre Onlinebefragung beginnt sofort nach der Eingabe.

- Tablet/Smartphone: Um sich anzumelden, geben Sie www.zew.de/umfrage2015 in die Adresszeile Ihres Internetbrowsers ein. Alternativ können sie auch den QR-Code neben diesem Absatz mit einer entsprechenden App auslesen. Auf beiden Wegen gelangen Sie auf den Startbildschirm. Auf diesem geben Sie Ihren persönlichen Zugangsschlüssel ein. Den Zugangsschlüssel entnehmen Sie bitte der ersten Seite des Einladungsschreibens. Dieser Zugangsschlüssel ermöglicht Ihnen eine einmalige Teilnahme. Ihre Onlinebefragung beginnt sofort nach der Eingabe.

Was passiert mit meinen Daten?

Ihre Angaben werden ausschließlich für wissenschaftliche Zwecke verwendet und in anonymisierter Form ausgewertet. Ihre persönlichen Angaben werden ausschließlich dazu genutzt, Ihnen Ihre Aufwandsentschädigung zu übermitteln und werden nicht mit den Angaben in der Befragung in Verbindung gebracht oder an Dritte weitergegeben.

Wie ermittelt sich meine Teilnahmevergütung?

Als Teilnahmevergütung erhalten Sie sowohl eine Teilnahmepauschale als auch eine zusätzliche Vergütung. Die Pauschale im Wert von 5 Euro erhalten Sie für Ihre Teilnahme in jedem Fall. Die darüber hinaus gehende zusätzliche Vergütung hängt in ihrem Wert sowohl von Ihren eigenen Entscheidungen als auch von denen anderer Teilnehmer ab.

Wie erhalte ich meine Teilnahmevergütung?

Um Ihnen eine Teilnahmevergütung ohne Angabe Ihrer Bankdaten ermöglichen zu können, erhalten Sie ca. 4 Wochen nach Ihrer Teilnahme einen Einkaufsgutschein per Post. Die Höhe des Gutscheins entspricht Ihrer gesamten Teilnahmevergütung (Teilnahmepauschale von 5 Euro plus zusätzliche Vergütung). Den Gutschein können Sie in einer Vielzahl von lokalen Geschäften und Online-Shops benutzen, um Ihre Einkäufe zu bezahlen (z. B. Galeria Kaufhof, Karstadt, Media Markt, Saturn - die volle Liste der den Gutschein akzeptierenden Geschäfte entnehmen Sie bitte dieser Website: http://www.edenred.de/produkte/ticketshopping-card/akzeptanzpartner.html) 


\section{Supplementary Material B: Experimental Instructions}

\section{Instructions and Questionnaire (translated from German)}

Explanation: Please note that these instructions are precise transcripts of the screens shown to the participants in the online experiment. We use square brackets [] to indicate the alternative wording [LABEL vs. NOLABEL] and parameters (HIGH vs. LOW) used in the different treatments. The term city district (set in italics) stands for one of the four different municipal districts Bahnstadt, Feudenheim, Neuenheim, and Schwetzingerstadt/Oststadt, depending on where the respective participant lives. In the following, we show the wording for the LOWNOLABEL as the benchmark case and as described above, we also show the deviations in the other treatments by using square brackets.

-Screen 1-

\section{Welcome to our research study!}

Dear participant,

Thank you for showing interest in this research study. You can start with the tasks immediately. On this screen you can find the most important information regarding your participation:

- Participating takes on average 15 minutes.

- There are two tasks and some questionnaires.

- All tasks will be precisely explained to you in the course of the study.

- All instructions will be carried out as described:

o By "money" we mean real amounts of money which will be definitely paid out to you.

o By "other participants" we mean real people who also participate in this study just like you.

Note: Please always use the buttons provided and not your internet browser for navigation because otherwise, a successful completion of the survey cannot be guaranteed.

-Screen 2-

\section{Your payment for participating consists of two parts:}

In any case, you will receive a fixed amount of 5 euros if you complete both tasks and complete the questionnaires.

- In task 1 or task 2, an additional payment may emerge for you and the other study participants.

- A random procedure (comparable with a coin flip) at the end of the study will determine whether you receive the payment from either task 1 or task 2 . Both outcomes are equally likely.

- We will definitely select and pay out one of the two tasks. You will receive the respective payment additionally to the fixed amount.

Thus, your total payment for participating in the study consists of the following: 
Your total payment $=5$ euros + payment from either task 1 or task 2

-Screen 3-

On the next screen, the first decision task starts. Please carefully read through the following explanations as they describe how your payment and the payments of the other study participants depend upon the decisions you make.

\section{-Screen 4-}

\section{Explanation and procedure of task 1}

In this section, you can earn money in addition to the fixed amount.

\section{Who are the other participants?}

All in all, 8 subjects actively take part in this decision task, namely you and 7 more participants. [LABEL: Apart from you, 3 other participants are, like you, inhabitants of city district. The other 4 participants are not inhabitants of city district but are from another area located in the RhineNeckar Metropolitan Region.]

\section{What is your task?}

In this task, you and all other participants are provided with 8 euros at your free disposal. Please note that you receive this amount of money in addition to the fixed amount. Your task is to decide on how to distribute the 8 euros across three different pots. Please note that the whole amount of 8 euros has to be distributed completely to the three different pots. Please also note that the other participants face the same decision situation as you do.

\section{How do the pots differ from each other?}

At the end of the study, the total sum of money allocated to all three pots is paid out to you and to the other participants according to the rules explained below. It depends on the pot $(\mathrm{A}, \mathrm{B}$, or C) whether either you, or you and 3 other participants, or you and 7 other participants benefit from the payment. Additionally, the total sum of money allocated to a certain pot may be multiplied before any payment from this pot is received.

Pot A (private): Only you can put an amount of money into this pot. For every euro that is contributed into this pot, you will receive 1 euro. The 7 other participants do not receive any payment from your pot. However, every participant owns a respective pot A as well.

Pot B (4 participants [ $L A B E L$ : city district]): Apart from you, there are $\mathbf{3}$ more participants [LABEL: from city district] (in total, 4 participants) who can put an amount of money into this pot. Every euro which is contributed to this pot will be doubled and the respective sum will be equally distributed to all 4 participants. For every euro that is put into Pot B, you and the 3 other participants [ $L A B E L$ : from city district] will consequently receive $\mathbf{0 . 5 0}$ euro each. The other group, which also comprises 4 participants, will not receive any payment from your Pot B. However, the other group owns a respective Pot B as well. 
Pot C (8 participants [LABEL: Rhine-Neckar Metropolitan Region]): Apart from you, there are 7 other participants [LABEL: from the Rhine-Neckar Metropolitan Region] (in total 8 participants) who can put an amount of money into this pot. Every euro which is put into this pot will be doubled [HIGH: quadrupled] and the respective sum will be equally distributed to all 8 participants. For every euro that is put into Pot $C$, you and the 7 other participants [LABEL: from the Rhine-Neckar Metropolitan Region] will consequently receive $\mathbf{0 . 2 5}$ euros [HIGH: 0.50 euros] each.

If task 1 is chosen for payment, your total payment is composed of the following elements:

Total payment $=5$ euro (lump sum) $+1.0 \times$ (sum of euros of Pot A) $+0.5 \times($ sum of euros of Pot B) + 0.25 [HIGH: 0.50] x (sum of euros of Pot C)

-Screen 5-

Please enter the amount of money you want to put into each of the three pots. Please remember that you are provided with 8 euros at your free disposal for this task of decision-making and you can decide on how to distribute this amount of money to the three different pots. For this purpose, please fill out the fields by entering an amount between 0 and 8 euros.

Pot A (private): $€$

Pot B (4 participants [LABEL: city district]): __ $€$

Pot C (8 participants [LABEL: Rhine-Neckar Metropolitan Region]):__€

Pot A (private): Only you can put an amount of money into this pot. For every euro that is contributed to this pot, you will receive 1 euro. The 7 other participants do not receive any payment from your pot. However, each participant owns a respective pot A as well.

Pot B (4 participants [ $L A B E L$ : city district]): Apart from you, there are $\mathbf{3}$ more participants [LABEL: from city district] (in total 4 participants) who can put an amount of money into this pot. Every euro which is put into this pot will be doubled and the respective sum will be equally distributed to all 4 participants. For every euro that is put into Pot B, you and the $\mathbf{3}$ other participants [LABEL: from city district] will consequently receive $\mathbf{0 . 5 0}$ euro each. The other group, which also comprises 4 participants, will not receive any payment from your Pot B. However, the other group owns a respective Pot B as well.

Pot C (8 participants [Rhine-Neckar Metropolitan Region]): Apart from you, there are 7 other participants [from the Rhine-Neckar Metropolitan Region] (in total 8 participants) who can put an amount of money into this pot. Every euro which is put into this pot will be doubled [HIGH: quadrupled] and the respective sum will be equally distributed to all 8 participants. For every euro that is put into Pot $\mathrm{C}$, you and the 7 other participants [LABEL: from the Rhine-Neckar Metropolitan Region] will consequently receive 0.25 euros [HIGH: 0.50 euros] each.

-Screen 6-

Before proceeding with task 2, we would like to gather some information about your district. 
Now we would like you to answer the following questions.

1. How strongly do you identify yourself with the Rhine-Neckar Metropolitan Region?

Please choose one of the following answers:

Not at all $\quad \square$ Slightly $\quad \square$ Moderately $\square$ Very $\quad \square$ Extremely $\square$ No statement

2. How strongly do you identify yourself with the district of city district?

Please choose one of the following answers:

Not at all $\square$ Slightly $\square$ Moderately $\square$ Very $\quad \square$ Extremely $\square$ No statement
-----------
Screen 8-

Now we would like you to answer the following questions.

1. Please indicate how much you, as an inhabitant of city district, agree with the following statements.

a) I deliberately decided to live in city district.

Please choose one of the following answers:

Not at all $\square$ Slightly $\square$ Moderately $\square$ Very $\quad \square$ Extremely $\square$ No statement

b) I actively participate in local organizations and groups which mainly consist of members who are inhabitants of city district.

Please choose one of the following answers:

Not at all $\square$ Slightly $\square$ Moderately $\quad \square$ Very $\quad \square$ Extremely $\square$ No statement

c) I am happy to live in city district.

Please choose one of the following answers:

Not at all $\square$ Slightly $\quad \square$ Moderately $\square$ Very $\quad \square$ Extremely $\square$ No statement

d) I participate in neighborhood activities together with other inhabitants of city district.

Please choose one of the following answers:

Not at all $\quad \square$ Slightly $\quad \square$ Moderately $\quad \square$ Very $\quad \square$ Extremely $\square$ No statement 
e) Recently, many new inhabitants have moved to city district.

Please choose one of the following answers:
Not at all $\square$ Slightly
$\square$ Moderately $\square$ Very
Extremely $\quad \square$ No statement

2. Please describe the positive aspects of [LOCAL PRIME: city district. REGIONAL PRIME: Rhine-Neckar Metropolitan Region] briefly in your own words.

Answer

-Screen 9-

On the next screen, the second decision task starts. Please carefully read through the following explanations as they describe how your payment and the payments of the other study participants depend on your decision.

-Screen 10-

\section{Explanation and procedure of task 2}

In this section, you can earn money in addition to the fixed amount.

\section{Who are the other participants?}

All in all, 8 subjects actively take part in this decision task, namely, you and 7 more participants. [LABEL: Apart from you, 3 other participants are, like you, inhabitants of city district. The other 4 participants are not inhabitants of city district but are from another area located in the RhineNeckar Metropolitan Region.]

\section{What is your task?}

In this task, you and all other participants are provided with 8 euros at your free disposal. Please note that you receive this amount of money in addition to the fixed amount. Your task is to decide on how to distribute the 8 euros across three different pots. Please note that the whole amount of 8 euros has to be distributed completely to the three different pots. Please also note that the other participants face the same decision situation as you do.

\section{How do the pots differ from each other?}

At the end of the study, the total sum of money allocated to all three pots is paid out to you and to the other participants according to the rules explained below. It depends on the pot (A, B, or C) if either you, or you and 3 other participants, or you and 7 other participants benefit from the payment. Additionally, the total sum of money allocated to a certain pot may be multiplied before any payment from this pot is received.

Pot A (private): Only you can put an amount of money into this pot. For every euro that is contributed into this pot, you will receive 1 euro. The 7 other participants do not receive any payment from your pot. However, every participant owns a respective pot A as well. 
Pot B (4 participants [ $L A B E L$ : city district]): Apart from you, there are $\mathbf{3}$ more participants [LABEL: from city district] (in total, 4 participants) who can put an amount of money into this pot. Every euro which is contributed to this pot will be doubled and the respective sum will be equally distributed to all 4 participants. For every euro that is put into Pot B, you and the $\mathbf{3}$ other participants [ $L A B E L$ : from city district] will consequently receive $\mathbf{0 . 5 0}$ euro each. The other group, which also comprises 4 participants, will not receive any payment from your Pot B. However, the other group owns a respective Pot B as well.

Pot C (8 participants [LABEL: Rhine-Neckar Metropolitan Region]): Apart from you, there are 7 other participants [LABEL: from the Rhine-Neckar Metropolitan Region] (in total, 8 participants) who can put an amount of money into this pot. Every euro which is put into this pot will be doubled [HIGH: quadrupled] and the respective sum will be equally distributed to all 8 participants. For every euro that is put into Pot C, you and the 7 other participants [LABEL: from the Rhine-Neckar Metropolitan Region] will consequently receive $\mathbf{0 . 2 5}$ euros [HIGH: 0.50 euros] each.

If task 1 is chosen for payment, your total payment is composed of the following elements:

Total payment $=5$ euro (lump sum) $+1.0 \times($ sum of euros of Pot A) $+0.5 \times($ sum of euros of Pot B) + 0.25 [HIGH: 0.50] x (sum of euros of Pot C)

-Screen 11-

Please enter the amount of money you want to put into each of the three pots. Please remember that you are provided with 8 euros at your free disposal for this task of decision-making and you can decide on how to distribute this amount of money to the three different pots. For this purpose, please fill out the fields by entering an amount between 0 and 8 euros.

Pot A (private): ——

Pot B (4 participants [LABEL: city district]): _€ $€$

Pot C (8 participants [LABEL: Rhine-Neckar Metropolitan Region]):_€ $€$

Pot A (private): Only you can put an amount of money into this pot. For every euro that is contributed to this pot, you will receive 1 euro. The 7 other participants do not receive any payment from your pot. However, each participant owns a respective pot A as well.

Pot B (4 participants [ $L A B E L$ : city district]): Apart from you, there are $\mathbf{3}$ more participants [LABEL: from city district] (in total, 4 participants) who can put an amount of money into this pot. Every euro which is put into this pot will be doubled and the respective sum will be equally distributed to all 4 participants. For every euro that is put into Pot B, you and the $\mathbf{3}$ other participants [ $L A B E L$ : from city district] will consequently receive 0.50 euro each. The other group, which also comprises 4 participants, will not receive any payment from your Pot B. However, the other group owns a respective Pot B as well.

Pot C (8 participants [Rhine-Neckar Metropolitan Region]): Apart from you, there are 7 other participants [from the Rhine-Neckar Metropolitan Region] (in total, 8 participants) who can put an amount of money into this pot. Every euro which is put into this pot will be doubled [HIGH: quadrupled] and the respective sum will be equally distributed to all 8 participants. For every 
euro that is put into Pot $\mathrm{C}$, you and the 7 other participants [LABEL: from the Rhine-Neckar Metropolitan Region] will consequently receive 0.25 euros [HIGH: 0.50 euros] each.

-Screen 12-

After you have made your decisions, we are interested in how you assess the behavior of the other participants in task 2 .

1. Regardless of your own decision: In your opinion, which decision did the other participants from your group [LABEL: from city district] make on average when they faced the same decision situation as you did?

Pot A: _ $€$ Pot B: _ $€$ Pot C: _ $€$

2. Regardless of your own decision: In your opinion, which decision did the other participants [LABEL: from the Rhine-Neckar Metropolitan Region] make on average when they faced the same decision situation as you did?

Pot A: — $€$ Pot B: _ $€$ Pot C: $\_€$

-Screen 13-

Now we would like to know your opinion about the comprehensibility of the tasks.

1. Please indicate how much you agree with the following statement: The instructions for the tasks were clear.

Please choose one of the following answers:

Not at all $\square$ Slightly $\quad \square$ Moderately $\square$ Very $\quad \square$ Extremely $\square$ No statement

2. Regardless of your actual decision: How would you have distributed the 8 euros to Pot A, Pot $\mathrm{B}$ and Pot $\mathrm{C}$ in task 2 if it had been your aim to maximize the total payment for yourself?

Pot A: _ $€$ Pot B: _ $€$ Pot C: $€ €$

3. Regardless of your actual decision: How would you have distributed the 8 euros to Pot A, Pot $\mathrm{B}$ and Pot $\mathrm{C}$ in task 2 if it had been your aim to maximize the total payment for all 8 participants in the decision task?

Pot A: _€ Pot B: _ $€$ Pot C: $€$ 
Thank you very much, you are almost done. Finally, we would like to ask you for some personal details.

-Screen 15-

Now we would like you to answer the following questions.

1. Please indicate how much you, as an inhabitant of the city district, agree with the following statements.

a) I am proud to live in the district of city district.

Please choose one of the following answers:

Not at all $\square$ Slightly $\quad \square$ Moderately $\square$ Very $\quad \square$ Extremely $\square$ No statement

b) I feel comfortable in the district of city district.

Please choose one of the following answers:

Not at all $\square$ Slightly $\quad \square$ Moderately $\quad \square$ Very $\quad \square$ Extremely $\square$ No statement

2. Self-assessment of your personality: In general, are you a person willing to take risks or are you more risk-averse?

Explanation about the scale: 0 (risk-averse) to 5 (prepared to take risks)

Please choose one of the following answers:
0
$\square 1$
$\square 2$
3
4

3. What is your opinion about the following three statements?

a) In general, people can be trusted.

Please choose one of the following answers:
Strongly
Disagree
$\square$ Agree
Strongly
$\square$ No statement
Disagree
Agree

b) Nowadays people are not reliable anymore.

Please choose one of the following answers:

\begin{tabular}{|c|c|c|}
\hline $\begin{array}{l}\text { Strongly } \\
\text { Disagree }\end{array}$ & $\square$ Disagree & $\square$ Agree \\
\hline
\end{tabular}


c) In dealing with strangers, it is better to be cautious before trusting them.

Please choose one of the following answers:

\begin{tabular}{|c|c|}
\hline $\begin{array}{l}\text { Strongly } \\
\text { Disagree }\end{array}$ & $\square$ Disagree \\
\hline
\end{tabular}

4. Do you think that most people...

Please choose one of the following answers:

... would take advantage of you if they had the possibility to do so...

...or would rather try to be fair to you?

No statement

5. In your opinion, would you say that most of the time people...

Please choose one of the following answers:

... try to be helpful...

...or only pursue their own interests?

No statement

6. Please specify your gender:

Please choose one of the following answers:

Male

Female

7. How old are you? years

8. For how long have you been living in the Rhine-Neckar Metropolitan Region?

For approximately years

9. For how long have you been living in the district of city district?

For approximately years

10. Do you consider yourself a member of a certain religious community?

Please choose one of the following answers:

Not at all $\square$ Slightly $\quad \square$ Moderately $\square$ Very $\quad \square$ Extremely $\square$ No statement

11. What are your native languages? 
12. In total, how much money does your household have at its disposal (net income) per month? Please choose one of the following answers:

$\begin{array}{lccccccc}\text { Up to } & \square 500 € & \square 1,000 € & \square 1,500 € \text { to } & \square 2,000 € & \square 3,000 \text { to } & \square \text { 4,000€ } & \square \text { No } \\ \text { less than } & \text { to } & \text { to } & 2,000 € & \text { to } & 4,000 € & \text { or more } & \text { statement } \\ 500 € & 1,000 € & 1,500 € & & 3,000 € & & & \end{array}$

13. Which party would you vote for if there were general elections to be held on next Sunday? Please choose one of the following answers:
$\mathrm{CDU} / \mathrm{CSU}$
FDP
I do not vote
SPD
Die Linke
No statement
Bündnis 90/Die
AfD
Other:

Grünen

14. What is the highest level of education you have received?

Please choose one of the following answers:

No qualification

Hauptschule (Secondary School Leaving Certificate)

Mittlere Reife (O level)

Fachhochschulreife (Advanced Technical College Certificate)

Abitur (A level / Higher Education Entrance Qualification)

Completed apprenticeship

University Diploma / Polytechnic Degree

No statement

Other qualification:

-Screen 16-

You will definitely receive 5eEuros for your participation. For the additional payment, there will be a procedure (comparable with a coin flip) which randomly determines whether you will receive the additional payment from task 1 or from task 2. Both outcomes are equally likely. We definitely choose and pay one of the two amounts. You will receive the respective payment additionally to the fixed amount.

Your total payment $=5$ euros + payment from either task 1 or task 2

As soon as all participants have made their decisions, we will inform you about the resulting total payment.

In order to allow you to receive your total payment without having to provide your personal bank data, you will receive a shopping voucher by mail approximately 4 weeks after your participation. The value of the voucher corresponds to your total payment. You can redeem the voucher to at numerous local shops and online shops (e.g. Galeria Kaufhof, Karstadt, Media Markt, Saturn). 
For this purpose, please enter your address:

Note: Your address will be used only for sending the shopping voucher and will not be transferred to third parties. Moreover, the data of the questionnaires will not be linked to your address data. If you have any questions concerning this research procedure, please do not hesitate to contact the directors of the study by calling $0621 / 1235-214$ or by email (umfrage@zew.de).

Name:

Surname:

Street Address:

Zip Code:

City:

Did you enjoy taking part in this study and do you want to participate in other scientific studies of this type?

We would be pleased to add your name to our members' database and would be happy to invite you to further studies. For this purpose, we only need your e-mail address. As a matter of course, your e-mail address is not used for any other purposes and if you wish to withdraw your participation offer at any future point, you will be directly unsubscribed from the database.

E-mail Address:

-Screen 17-

Thank you very much!

Your answers were stored. 


\section{Instructions and Questionnaire (in German)}

-Screen 1-

\section{Herzlich Willkommen zur wissenschaftlichen Studie!}

Sehr geehrte Teilnehmerin, sehr geehrter Teilnehmer,

vielen Dank für Ihr Interesse! Gleich können Sie mit der Bearbeitung beginnen. Vorab finden Sie hier die wichtigsten Eckpunkte zu Ihrer Teilnahme:

- Die Teilnahme dauert durchschnittlich 15 Minuten.

- Sie umfasst zwei Aufgaben sowie Fragebögen.

- Beide Aufgaben werden Ihnen im Laufe der Studie genau erklärt.

- Alle Erklärungen werden dabei so umgesetzt wie beschrieben:

o Ist von Geldbeträgen die Rede, so handelt es sich um reale Beträge, die tatsächlich ausbezahlt werden.

o Ist von anderen Studienteilnehmern die Rede, so handelt es sich um reale Teilnehmer, die wie Sie an dieser Studie teilnehmen.

Bitte beachten Sie: Nutzen Sie zur Navigation stets die bereitgestellten Schaltflächen und nicht Ihren Internetbrowser, da sonst ein erfolgreicher Abschluss der Umfrage nicht gewährleistet ist.

-Screen 2-

\section{Ihre Teilnahmevergütung setzt sich aus zwei Bestandteilen zusammen:}

Wenn Sie beide Aufgaben sowie die Fragebögen abschließen, erhalten Sie in jedem Fall eine Teilnahmepauschale im Wert von 5 Euro.

- In Aufgabe 1 oder Aufgabe 2 werden zusätzliche Auszahlungen für Sie und die anderen Teilnehmer der Studie entstehen.

- Im Anschluss an die Studie wird per Zufall (vergleichbar mit einem Münzwurf) entschieden, ob Sie die zusätzliche Auszahlung aus Aufgabe 1 oder Aufgabe 2 erhalten. Beides ist gleich wahrscheinlich.

- Es wird auf jeden Fall eine der beiden Aufgaben ausgewählt. Die hieraus entstehenden Auszahlungen erhalten Sie zusätzlich zur Teilnahmepauschale.

Ihre gesamte Teilnahmevergütung für die Studienteilnahme setzt sich somit folgendermaßen zusammen:

Ihre Gesamtauszahlung = 5 Euro + Auszahlung aus Aufgabe 1 oder aus Aufgabe 2

\section{Screen 3-}

Auf dem nächsten Bildschirm beginnt die erste Entscheidungsaufgabe. Bitte lesen Sie sich die folgenden Erklärungen genau durch, da dort beschrieben wird, wie Ihre Auszahlungen und die der anderen Studienteilnehmer von Ihren Entscheidungen abhängen. 
In diesem Teil können Sie zusätzlich zur Teilnahmepauschale Geld verdienen.

\section{Wer sind die anderen Teilnehmer?}

Insgesamt nehmen an dieser Entscheidungsaufgabe 8 Personen teil: Sie selbst und 7 weitere Personen. [LABEL: Von diesen 7 weiteren Personen kommen 3 Teilnehmer, wie Sie, aus city district und 4 Teilnehmer aus einem anderen Gebiet der Metropolregion Rhein-Neckar.]

\section{Was ist die Aufgabe?}

Ihnen und allen anderen Teilnehmern stehen im Rahmen dieser Entscheidungsaufgabe jeweils 8 Euro zur freien Verfügung. Bitte beachten Sie, dass Sie diesen Betrag zusätzlich zu Ihrer Teilnahmepauschale erhalten. Ihre Aufgabe besteht darin, zu entscheiden, wie Sie diese 8 Euro auf drei verschiedene Töpfe aufteilen möchten. Wichtig dabei ist, dass Sie diese 8 Euro vollständig auf die drei verschiedenen Töpfe aufteilen müssen. Bitte beachten Sie, dass jeder der anderen Teilnehmer vor derselben Entscheidungssituation steht wie Sie.

\section{Wie unterscheiden sich die drei Töpfe?}

Die Gesamtsumme an Geldbeträgen, die sich in jedem der drei Töpfe befindet, wird am Ende der Studie nach den unten beschriebenen Regeln an Sie und die anderen Teilnehmer ausbezahlt. Je nach Topf (A, B, oder C) kommt diese Auszahlung nur Ihnen, Ihnen und 3 weiteren Teilnehmern, oder Ihnen und allen 7 weiteren Teilnehmern zugute. Zudem wird die Gesamtsumme in bestimmten Töpfen vor der Auszahlung vervielfacht.

Topf A (Privat): In diesen Topf können nur Sie selbst einen Geldbetrag legen. Für jeden Euro, der sich am Ende in Topf A befindet, erhalten Sie 1 Euro. Die 7 weiteren Teilnehmer an dieser Entscheidungsaufgabe erhalten aus Ihrem Topf A keine Auszahlung. Jeder Teilnehmer verfügt jedoch über einen entsprechenden eigenen Topf A.

Topf B (4 Teilnehmer [LABEL: city district]): In diesen Topf können neben Ihnen noch 3 weiteren Teilnehmer [LABEL: aus city district] (also insgesamt 4 Teilnehmer) einen Geldbetrag legen. Jeder einbezahlte Euro wird verdoppelt und die entsprechende Summe unter diesen 4 Teilnehmern gleichmäßig verteilt: Für jeden Euro, der sich am Ende in Topf B befindet, erhalten somit Sie und die 3 weiteren Teilnehmer [ $L A B E L$ : aus city district] 0,50 Euro. Die übrigen 4 Teilnehmer erhalten aus Ihrem Topf B keine Auszahlung. Diese 4 Teilnehmer verfügen jedoch über einen entsprechenden eigenen Topf B.

Topf C (8 Teilnehmer [LABEL: Metropolregion Rhein-Neckar]): In diesen Topf können neben Ihnen alle 7 weiteren Teilnehmer [LABEL: aus der Metropolregion Rhein-Neckar] einen Geldbetrag legen (also insgesamt 8 Teilnehmer). Jeder einbezahlte Euro wird verdoppelt [HIGH: vervierfacht] und die entsprechende Summe unter allen 8 Teilnehmern gleichmäßig verteilt: Für jeden Euro, der sich am Ende in Topf $C$ befindet, erhalten somit Sie und die 7 weiteren Teilnehmer [LABEL: aus der Metropolregion Rhein-Neckar] jeweils 0,25 Euro [HIGH: 0,50 Euro]. 
Falls Aufgabe 1 zur Auszahlung herangezogen wird, sieht Ihre Gesamtauszahlung wie folgt aus:

Gesamtauszahlung $=5$ Euro $($ Teilnahmepauschale $)+1,0 \times$ (Summe an Euros in Topf A) $+0,5 \times$ (Summe an Euros in Topf B)

$$
+0,25 \text { [HIGH: 0,50] } \mathrm{x} \text { (Summe an Euros in Topf }
$$

\section{-Screen 5-}

Bitte teilen Sie uns mit, welchen Geldbetrag Sie in jeden der drei Töpfe legen wollen. Zur Erinnerung: Für diese Entscheidungsaufgabe stehen Ihnen insgesamt 8 Euro zur freien Verfügung und Sie können diesen Betrag beliebig auf die drei Töpfe aufteilen. Hierzu tragen Sie bitte in jedes dieser Felder einen Betrag zwischen 0 und 8 Euro ein.

Topf A (Privat): $€$

Topf B (4 Teilnehmer [LABEL: city district]): $€$

Topf C (8 Teilnehmer [LABEL: Metropolregion Rhein-Neckar]): $€$

Topf A (Privat): In diesen Topf können nur Sie selbst einen Geldbetrag legen. Für jeden Euro, der sich am Ende in Topf A befindet, erhalten Sie 1 Euro. Die 7 weiteren Teilnehmer an dieser Entscheidungsaufgabe erhalten aus Ihrem Topf A keine Auszahlung. Jeder Teilnehmer verfügt jedoch über einen entsprechenden eigenen Topf A.

Topf B (4 Teilnehmer [LABEL: city district]): In diesen Topf können neben Ihnen noch 3 weiteren Teilnehmer [LABEL: aus city district] (also insgesamt 4 Teilnehmer) einen Geldbetrag legen. Jeder einbezahlte Euro wird verdoppelt und die entsprechende Summe unter diesen 4 Teilnehmern gleichmäßig verteilt: Für jeden Euro, der sich am Ende in Topf B befindet, erhalten somit Sie und die 3 weiteren Teilnehmer [ $L A B E L$ : aus city district] 0,50 Euro. Die übrigen 4 Teilnehmer erhalten aus Ihrem Topf B keine Auszahlung. Diese 4 Teilnehmer verfügen jedoch über einen entsprechenden eigenen Topf B.

Topf C (8 Teilnehmer [LABEL: Metropolregion Rhein-Neckar]): In diesen Topf können neben Ihnen alle 7 weiteren Teilnehmer [LABEL: aus der Metropolregion Rhein-Neckar] einen Geldbetrag legen (also insgesamt 8 Teilnehmer). Jeder einbezahlte Euro wird verdoppelt [HIGH: vervierfacht] und die entsprechende Summe unter allen 8 Teilnehmern gleichmäßig verteilt: Für jeden Euro, der sich am Ende in Topf $C$ befindet, erhalten somit Sie und die 7 weiteren Teilnehmer [LABEL: aus der Metropolregion Rhein-Neckar] jeweils 0,25 Euro [HIGH: 0,50 Euro].

-Screen 6-

Bevor die zweite Aufgabe folgt, bitten wir Sie nun um einige Angaben zu Ihrem Stadtteil.

-Screen 7-

Jetzt möchten wir Sie bitten, folgende Fragen zu beantworten. 
1. Wie stark identifizieren Sie sich mit der Metropolregion Rhein-Neckar?

Bitte wählen Sie eine der folgenden Antworten:

$\begin{aligned} & \text { Überhaupt } \\ & \text { nicht }\end{aligned} \quad \square$ Eher nicht $\quad \square$ Teils, teils $\square$ Stark $\square$ Sehr stark $\square$ Keine
Angabe

2. Wie stark identifizieren Sie sich mit dem Stadtteil city district?

Bitte wählen Sie eine der folgenden Antworten:
Überhaupt $\square$ Eher nicht $\quad \square$ Teils, teils
Stark
Sehr stark
Keine nicht
Angabe

\section{-Screen 8-}

Jetzt möchten wir Sie bitten, folgende Fragen zu beantworten.

1. Bitte geben Sie an, wie stark Sie, als Bewohnerin bzw. Bewohner des Statteils city district, den folgenden Aussagen zustimmen.

a) Ich habe mich bewusst dazu entschieden, im Stadtteil city district zu leben.

Bitte wählen Sie eine der folgenden Antworten:

Überhaupt $\square$ Eher nicht $\quad \square$ Teils, teils $\square$ Stark $\quad \square$ Sehr stark $\begin{aligned} & \square \text { Keine } \\ & \text { nicht }\end{aligned}$
Angabe

b) Ich bin aktiv in lokalen Organisationen oder Gruppen, die zum Großteil aus

Bewohnerinnen und Bewohnern des Stadtteils city district bestehen.

Bitte wählen Sie eine der folgenden Antworten:
Überhaupt $\quad \square$ Eher nich
$\square$ Teils, teils
Stark
Sehr stark
Keine nicht
Angabe

c) Ich bin glücklich, im Stadtteil city district zu leben.

Bitte wählen Sie eine der folgenden Antworten:
Überhaupt $\square$ Eher nicht
Sehr stark
Keine nicht
Stark
$\square$ Teils, teils
(2)
Angabe

d) Ich nehme an Nachbarschaftsaktivitäten zusammen mit anderen Bewohnerinnen und Bewohnern des Stadtteils city district teil.

Bitte wählen Sie eine der folgenden Antworten:
Überhaupt $\square$ Eher nicht $\quad \square$ Teils, teils
Stark
Sehr stark
$\square$ Keine nicht
Angabe 
e) Im Stadtteil city district sind in letzter Zeit viele neue Bewohnerinnen und Bewohner zugezogen.

Bitte wählen Sie eine der folgenden Antworten:

$\begin{aligned} & \text { Überhaupt } \\ & \text { nicht }\end{aligned} \quad \square$ Eher nicht $\quad \square$ Teils, teils $\square$ Stark $\quad \square$ Sehr stark $\begin{aligned} & \square \text { Keine } \\ & \text { Angabe }\end{aligned}$

2. Bitte beschreiben Sie kurz in eigenen Worten die positive Aspekte [LOCAL PRIME: des Stadtteils city district. REGIONAL PRIME: der Metropolregion Rhein-Neckar].

Amtwort

\section{-Screen 9-}

Auf dem nächsten Bildschirm beginnt die zweite Entscheidungsaufgabe. Bitte lesen Sie sich die folgenden Erklärungen genau durch, da dort beschrieben wird, wie Ihre Auszahlungen und die der anderen Studienteilnehmer von Ihren Entscheidungen abhängen.

-Screen 10-

\section{Erklärung und Ablauf Aufgabe 2}

Auch in diesem Teil können Sie zusätzlich zur Teilnahmepauschale Geld verdienen.

\section{Wer sind die anderen Teilnehmer?}

Insgesamt nehmen an dieser Entscheidungsaufgabe 8 Personen teil: Sie selbst und 7 weitere Personen. [LABEL: Von diesen 7 weiteren Personen kommen 3 Teilnehmer, wie Sie, aus city district und 4 Teilnehmer aus einem anderen Gebiet der Metropolregion Rhein-Neckar.]

\section{Was ist die Aufgabe?}

Ihnen und allen anderen Teilnehmern stehen im Rahmen dieser Entscheidungsaufgabe jeweils 8 Euro zur freien Verfügung. Bitte beachten Sie, dass Sie diesen Betrag zusätzlich zu Ihrer Teilnahmepauschale erhalten. Ihre Aufgabe besteht darin, zu entscheiden, wie Sie diese 8 Euro auf drei verschiedene Töpfe aufteilen möchten. Wichtig dabei ist, dass Sie diese 8 Euro vollständig auf die drei verschiedenen Töpfe aufteilen müssen. Bitte beachten Sie, dass jeder der anderen Teilnehmer vor derselben Entscheidungssituation steht wie Sie.

\section{Wie unterscheiden sich die drei Töpfe?}

Die Gesamtsumme an Geldbeträgen, die sich in jedem der drei Töpfe befindet, wird am Ende der Studie nach den unten beschriebenen Regeln an Sie und die anderen Teilnehmer ausbezahlt. Je nach Topf (A, B, oder C) kommt diese Auszahlung nur Ihnen, Ihnen und 3 weiteren Teilnehmern, oder Ihnen und allen 7 weiteren Teilnehmern zugute. Zudem wird die Gesamtsumme in bestimmten Töpfen vor der Auszahlung vervielfacht. 
Topf A (Privat): In diesen Topf können nur Sie selbst einen Geldbetrag legen. Für jeden Euro, der sich am Ende in Topf A befindet, erhalten Sie 1 Euro. Die 7 weiteren Teilnehmer an dieser Entscheidungsaufgabe erhalten aus Ihrem Topf A keine Auszahlung. Jeder Teilnehmer verfügt jedoch über einen entsprechenden eigenen Topf A.

Topf B (4 Teilnehmer [LABEL: city district]): In diesen Topf können neben Ihnen noch 3 weiteren Teilnehmer [LABEL: aus city district] (also insgesamt 4 Teilnehmer) einen Geldbetrag legen. Jeder einbezahlte Euro wird verdoppelt und die entsprechende Summe unter diesen 4 Teilnehmern gleichmäßig verteilt: Für jeden Euro, der sich am Ende in Topf B befindet, erhalten somit Sie und die 3 weiteren Teilnehmer [ $L A B E L$ : aus city district] 0,50 Euro. Die übrigen 4 Teilnehmer erhalten aus Ihrem Topf B keine Auszahlung. Diese 4 Teilnehmer verfügen jedoch über einen entsprechenden eigenen Topf B.

Topf C (8 Teilnehmer [LABEL: Metropolregion Rhein-Neckar]): In diesen Topf können neben Ihnen alle 7 weiteren Teilnehmer [LABEL: aus der Metropolregion Rhein-Neckar] einen Geldbetrag legen (also insgesamt 8 Teilnehmer). Jeder einbezahlte Euro wird verdoppelt [HIGH: vervierfacht] und die entsprechende Summe unter allen 8 Teilnehmern gleichmäßig verteilt: Für jeden Euro, der sich am Ende in Topf $C$ befindet, erhalten somit Sie und die 7 weiteren Teilnehmer [LABEL: aus der Metropolregion Rhein-Neckar] jeweils 0,25 Euro [HIGH: 0,50 Euro].

Falls Aufgabe 1 zur Auszahlung herangezogen wird, sieht Ihre Gesamtauszahlung wie folgt aus:

Gesamtauszahlung = 5 Euro (Teilnahmepauschale $)+1,0 \times$ (Summe an Euros in Topf A) $+0,5 \times$ (Summe an Euros in Topf B)

$+0,25$ [HIGH: 0,50] $\mathrm{x}$ (Summe an Euros in Topf

-Screen 11-

Bitte teilen Sie uns mit, welchen Geldbetrag Sie in jeden der drei Töpfe legen wollen. Zur Erinnerung: Für diese Entscheidungsaufgabe stehen Ihnen insgesamt 8 Euro zur freien Verfügung und Sie können diesen Betrag beliebig auf die drei Töpfe aufteilen. Hierzu tragen Sie bitte in jedes dieser Felder einen Betrag zwischen 0 und 8 Euro ein.

Topf A (Privat): __ $€$

Topf B (4 Teilnehmer [LABEL: city district]): __ $€$

Topf C (8 Teilnehmer [LABEL: Metropolregion Rhein-Neckar]): $€$

Topf A (Privat): In diesen Topf können nur Sie selbst einen Geldbetrag legen. Für jeden Euro, der sich am Ende in Topf A befindet, erhalten Sie 1 Euro. Die 7 weiteren Teilnehmer an dieser Entscheidungsaufgabe erhalten aus Ihrem Topf A keine Auszahlung. Jeder Teilnehmer verfügt jedoch über einen entsprechenden eigenen Topf A.

Topf B (4 Teilnehmer [LABEL: city district]): In diesen Topf können neben Ihnen noch 3 weiteren Teilnehmer [LABEL: aus city district] (also insgesamt 4 Teilnehmer) einen Geldbetrag legen. Jeder einbezahlte Euro wird verdoppelt und die entsprechende Summe unter diesen 4 Teilnehmern gleichmäßig verteilt: Für jeden Euro, der sich am Ende in Topf B befindet, erhalten somit Sie und die 3 weiteren Teilnehmer [ $L A B E L$ : aus city district] 0,50 
Euro. Die übrigen 4 Teilnehmer erhalten aus Ihrem Topf B keine Auszahlung. Diese 4 Teilnehmer verfügen jedoch über einen entsprechenden eigenen Topf B.

Topf C (8 Teilnehmer [LABEL: Metropolregion Rhein-Neckar]): In diesen Topf können neben Ihnen alle 7 weiteren Teilnehmer [LABEL: aus der Metropolregion Rhein-Neckar] einen Geldbetrag legen (also insgesamt 8 Teilnehmer). Jeder einbezahlte Euro wird verdoppelt [HIGH: vervierfacht] und die entsprechende Summe unter allen 8 Teilnehmern gleichmäßig verteilt: Für jeden Euro, der sich am Ende in Topf $C$ befindet, erhalten somit Sie und die 7 weiteren Teilnehmer [LABEL: aus der Metropolregion Rhein-Neckar] jeweils 0,25 Euro [HIGH: 0,50 Euro].

\section{-Screen 12-}

Nachdem Sie Ihre Entscheidungen getroffen haben, interessiert uns, wie Sie das Verhalten von anderen Teilnehmern in Aufgabe 2 einschätzen.

1. Unabhängig von Ihrer eigenen Entscheidung: Wie haben sich Ihrer Meinung nach im Durchschnitt andere Teilnehmer Ihrer Gruppe [LABEL: aus city dicstrict] entschieden, die in der gleichen Entscheidungssituation wie Sie waren?

Topf A:

$€$ Topf B:

$€$ Topf C: $€$

2. Unabhängig von Ihrer eigenen Entscheidung: Wie haben sich Ihrer Meinung nach im Durchschnitt die anderen Teilnehmer [LABEL: aus der gesamten Metropolregion RheinNeckar] entschieden, die in der gleichen Entscheidungssituation wie Sie waren?

Topf A: $€$ Topf B:

$€$ Topf C: $€$

-Screen 13-

Nun interessiert uns, wie verständlich aus Ihrer Sicht die Aufgaben waren.

1. Bitte geben Sie an, wie stark Sie der folgenden Aussage zustimmen: Ich fand die Aufgaben verständlich erklärt.

Bitte wählen Sie eine der folgenden Antworten:

Überhaupt $\square$ Eher nicht $\quad \square$ Teils, teils $\square$ Stark $\square$ Sehr stark $\begin{aligned} & \text { Keine } \\ & \text { nicht }\end{aligned}$
Angabe


2. Unabhängig von Ihrer tatsächlichen Entscheidung: Wie hätten Sie in Aufgabe 2 die 8 Euro über Topf A, Topf B und Topf C verteilen sollen, wenn es Ihr Ziel gewesen wäre, die höchstmögliche Aufwandsentschädigung für Sie selbst zu erhalten?

Topf A: $€$ Topf B:

$€$ Topf C: $€$

3. Unabhängig von Ihrer tatsächlichen Entscheidung: Wie hätten Sie in Aufgabe 2 die 8 Euro über Topf A, Topf B und Topf C verteilen sollen, wenn es Ihr Ziel gewesen wäre, die höchstmögliche Aufwandsentschädigung für alle 8 Teilnehmer in der Entscheidungsaufgabe zu erhalten?

Topf A: $€$ Topf B: $€$ Topf C: $€$

-Screen 14-

Vielen Dank, Sie haben es fast geschafft. Abschließend bitten wir Sie um einige Angaben zu Ihrer Person.

-Screen 15-

Jetzt möchten wir Sie bitten, folgende Fragen zu beantworten.

1. Bitte geben Sie an, wie stark Sie als Bewohnerin bzw. Bewohner des Stadtteils city district, den folgenden Aussagen zustimmen.

a) Ich bin stolz darauf, im Stadtteil city district zu leben.

Bitte wählen Sie eine der folgenden Antworten:

Überhaupt $\square$ Eher nicht $\quad \square$ Teils, teils $\quad \square$ Stark $\quad \square$ Sehr stark $\begin{aligned} & \square \text { Keine } \\ & \text { nicht }\end{aligned}$
Angabe

b) Ich fühle mich im Stadtteil city district wohl.

Bitte wählen Sie eine der folgenden Antworten:
Überhaupt
Eher nicht
$\square$ Teils, teils
Stark nicht
Sehr stark
Keine
Angabe

2. Wie schätzen Sie sich persönlich ein: Sind Sie im Allgemeinen ein risikobereiter Mensch oder versuchen Sie, Risiken zu vermeiden?

Erklärung zur Skala: 0 (gar nicht risikobereit) bis 5 (sehr risikobereit)

Bitte wählen Sie eine der folgenden Antworten:
0
$\square 1$
$\square 2$
3
4
$\square 5$
Keine Angabe 
3. Wie ist Ihre Meinung zu den folgenden drei Aussagen?

a) Im Allgemeinen kann man den Menschen vertrauen.

Bitte wählen Sie eine der folgenden Antworten:

Lehne voll ab $\quad \square$ Lehne eher ab $\quad \square$ Stimme eher $\mathrm{zu}$
Stimme voll

$\mathrm{zu}$

Keine Angabe

b) Heutzutage kann man sich auf niemanden mehr verlassen.

Bitte wählen Sie eine der folgenden Antworten:

Lehne voll ab $\square$ Lehne eher ab $\quad \square$ Stimme eher $\quad \square$ Stimme voll $\quad \square$ Keine Angabe
zu

c) Wenn man mit Fremden zu tun hat, ist es besser, vorsichtig zu sein, bevor amn ihnen vertratut.

Bitte wählen Sie eine der folgenden Antworten:
Lehne voll ab $\square$ Lehne eher ab $\square$ Stimme eher
Stimme voll
$\mathrm{Zu}$
Keine Angabe

4. Glauben Sie, dass die moisten Leute...

Bitte wählen Sie eine der folgenden Antworten:

...Sie ausnutzen würden, falls sie eine Möglichkeit dazu hätten...

...oder versuchen würden, Ihnen gegenüber fair zu sein?

Keine Angabe

5. Würden Sie sagen, dass die Leute die meiste Zeit...

Bitte wählen Sie eine der folgenden Antworten:

... versuchen, hilfsbereit zu sein...

...oder nur Ihre eigenen Interessen verfolgen?

Keine Angabe

6. Bitte geben Sie Ihr Geschlecht an:

Bitte wählen Sie eine der folgenden Antworten:

Männlich

Weiblich

7. Wie alt sind Sie? Jahre 
8. Wie lange leben Sie bereits in der Metropolregion Rhein-Neckar?

Seit ca. Jahren

9. Wie lange leben Sie bereits im Stadtteil city district?

Seit ca. Jahren

10.Fühlen Sie sich einer Religionsgemeinschaft zugehörig?

Bitte wählen Sie eine der folgenden Antworten:

Überhaupt $\square$ Eher nicht $\quad \square$ Teils, teils $\square$ Stark $\square$ Sehr stark $\square$ Keine
nicht

11. Welche Muttersprache(n) sprechen Sie?

12. Wie viel Geld steht Ihrem Haushalt insgesamt pro Monat zur Verfügung (Nettoeinkommen)?

Bitte wählen Sie eine der folgenden Antworten:

$\begin{array}{lccccccc}\text { Bis unter } & \square 500 € & \square 1.000 € & \square 1.500 € \text { to } & \square 2.000 € & \square 3.000 & \square \text { 4.000€ } & \square \text { Keine } \\ 500 € & \text { bis } & \text { bis } & 2.000 € & \text { bis } & \text { bis } & \text { und } & \text { Angabe } \\ & 1.000 € & 1.500 € & & 3.000 € & 4.000 € & \text { mehr } & \end{array}$

13. Welche Partei würden Sie wählen, wenn am nächsten Sonntag Bundestagswahl wäre? Bitte wählen Sie eine der folgenden Antworten:
$\mathrm{CDU} / \mathrm{CSU}$
FDP
Ich gehe nicht wählen
SPD
Die Linke
Keine Angabe
Bündnis 90/Die
AfD
Sonstige:

Grünen

14. Was ist Ihr höchster Bildungsabschluss?

Bitte wählen Sie eine der folgenden Antworten:

Kein Schulabschluss

Hauptschule

Mittlere Reife

Fachhochschulreife

Abitur (Hochschulreife)

Abgeschlossene Ausbildung

Universitäts-/Fachhochschulabschluss

Keine Angabe

Anderer Abschluss: 
Für Ihre Teilnahme erhalten Sie in jedem Fall 5 Euro. Für die zusätzliche Auszahlung wird per Zufall (vergleichbar mit einem Münzwurf) entschieden, ob Sie die zusätzliche Auszahlung aus Aufgabe 1 oder Aufgabe 2 erhalten. Beides ist gleich wahrscheinlich. Es wird auf jeden Fall eine der beiden Aufgaben ausgezahlt. Die hieraus entstehende Auszahlung erhalten Sie zusätzlich zur Teilnahemepauschale.

Ihre Gesamtauszahlung = 5 Euro + Auszahlung aus Aufgabe 1 oder aus Aufgabe 2

Sobald alle Teilnehmer ihre Entscheidungen getroffen haben, werden wir Ihnen die entstandene Gesamtauszahlung mitteilen.

Um Ihnen eine Teilnahmevergütung ohne Angabe Ihrer Bankdaten ermöglichen zu können, erhalten Sie ca. 4 Wochen nach Ihrer Teilnahme einen Einkaufsgutschein per Post. Die Höhe des Gutscheins entspricht Ihrer gesamten Teilnahmevergütung. Den Gutschein können Sie in einer Vielzahl von lokalen Geschäften und Online-Shops benutzen, um Ihre Einkäufe zu bezahlen (z.B. Galeria Kaufhof, Karstadt, Media Markt, Saturn).

Bitte geben Sie hierzu Ihre Adresse ein:

Hinweis: Ihre Adresse wird ausschließlich für den Versand des Einkaufsgutscheins verwendet und nicht an Dritte weitergegeben. Auch die Daten aus dem Fragebogen werden nicht mit den Adressdaten verknüpft. Sollten Sie zu diesem Ablauf Fragen haben, können Sie die Studienleitung unter der Rufnummer 0621/1235-214 oder per E-Mail (umfrage@zew.de)

Name:

Vorname:

Straße und Hausnummer:

Postleitzahl:

Stadt:

Hat Ihnen die Teilnahme Spaß gemacht und können Sie sich vorstellen an weiteren wissenschaftlichen Studien dieser Art teilzunehmen?

Wir nehmen Sie gerne in unsere Teilnehmerdatenbank auf und laden Sie zu weiteren Studien ein. Dazu benötigen wir lediglich Ihre E-Mail Adresse. Selbstverständlich wird diese nicht für andere Zwecke weitergegeben und Sie können sich jederzeit aus der Datenbank austragen lassen.

E-Mail Adresse:

-Screen 17-

Vielen Dank!

Ihre Antworten wurden gespeichert. 


\section{Supplementary Material C: Power Calculations}

\section{Figure S.2: Power calculation for MPCR effect}

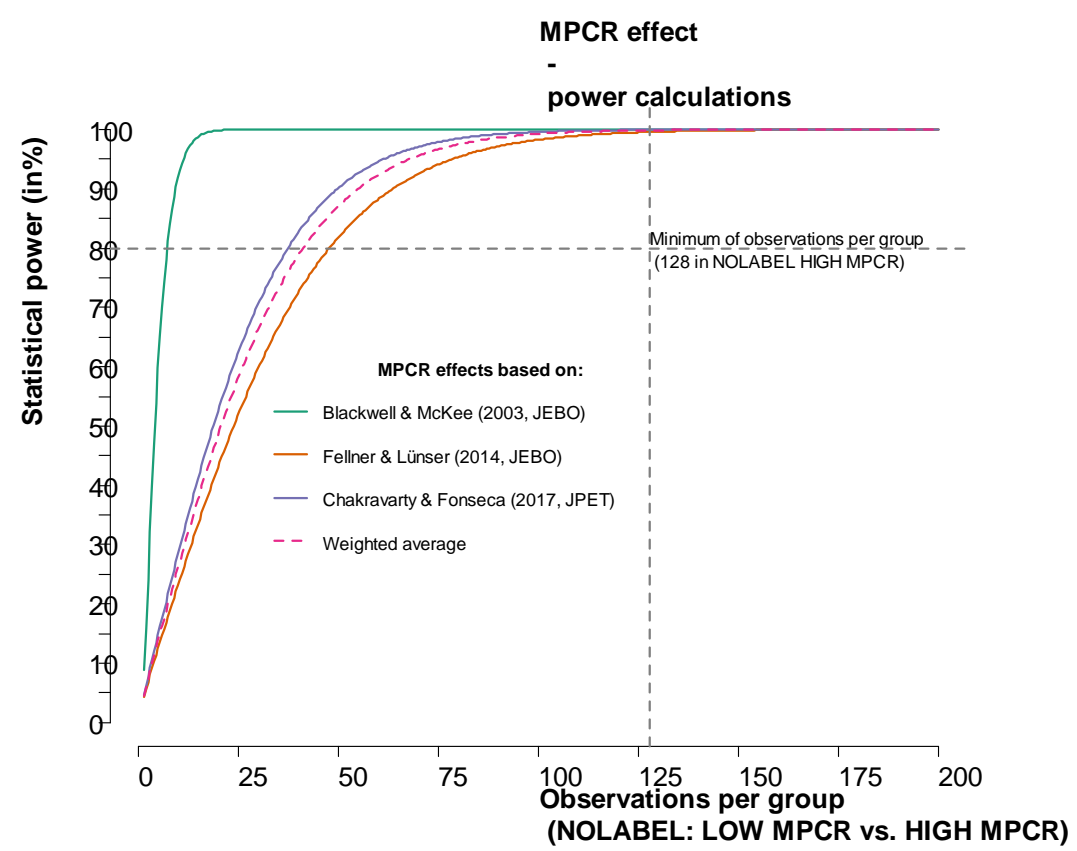

Note: Power curves for priors of MPCR effects derived from previously conducted laboratory experiments as well as average prior (red dashed line), weighted by the number of participants per treatment in these experiments. Power calculations are based on a two-sided t-test of means with independent samples conducted in $\mathrm{R}^{1}$ using the “pwr” package 2 .

MPCR effect. We derive our prior for the size of the MPCR effect in NOLABEL from previously conducted laboratory experiments by Blackwell and McKee (2003) ${ }^{3}$, Fellner and Lünser (2014) ${ }^{4}$, and Chakravarty and Fonseca $(2017)^{5}$ which all investigate a MPCR effect in multi-level public goods provision. Based on these priors, we substantially oversample participants allowing us to detect a MPCR effect similar to those reported in these previous studies at a very high level of statistical power ${ }^{6}$ (>95\%). Figure S.2 depicts, for each of these individual studies as well as their weighted study average MPCR effect, a power curve that

\footnotetext{
1 R Core Team (2018), R: A language and environment for statistical computing. R Foundation for Statistical Computing, Vienna, Austria. https://www.R-project.org/

2 Champely S (2018), pwr: Basic Functions for Power Analysis. R package version 1.2-2. https://CRAN.Rproject.org/package=pwr

${ }^{3}$ Blackwell C, McKee M (2003), Only for my own neighborhood? Preferences and voluntary provision of local and global public goods, Journal of Economic Behavior and Organization, 52, 115-131.

${ }^{4}$ Fellner G, Lünser G (2014), Cooperation in local and global groups, Journal of Economic Behavior \& Organization, 108, 364-373.

${ }^{5}$ Chakravarty S, Fonseca M (2017), Discrimination via exclusion: An experiment on group identity and club goods, Journal of Public Economic Theory, 19, 244-263.

${ }^{6}$ With statistical power we refer to the probability that a hypotheses test rejects the null hypothesis $\left(\mathrm{H}_{0}\right)$ when a specific alternative hypothesis is true $\left(\mathrm{H}_{1}\right)$.
} 
illustrates this oversampling. We have approximately 120 participants per treatment cell where around 40 would have been sufficient to detect a MPCR effect similar to those observed in the previously conducted experiments at conventional levels of statistical significance (5\%) and power (80\%). Put differently, we have sufficient statistical power to identify an MPCR effect that is substantially smaller than in the previous literature.

Parochial bias. We define the hypothetical effect size of the parochial bias in our experiment as a reduction of the MPCR effect in LABEL compared to the MPCR effect in NOLABEL. To simulate a variety of parochial biases, we use the MPCR effects observed in previously conducted laboratory experiments (as cited above, see MPCR effect) and define the parochial bias in LABEL as a percentage reduction of this effect. A parochial bias of $0 \%$ would imply that both MPCR effect in LABEL and NOLABEL are of the same size. Similarly, a parochial bias of 50\% would imply the MPCR effect in LABEL should only be half of the size of the MPCR effect in NOLABEL. A parochial bias of $100 \%$ would imply that there is no MPCR effect in LABEL. In a first step of our power calculation, we use the results from the existing literature to derive estimates for the four means and corresponding standard deviations we expect to see in our two-by-two design. Importantly, contributions in our HIGH MPCR LABEL treatment are modeled as contributions in LOW MPCR LABEL plus MPCR effect that is reduced by the parochial bias. Based on these predicted values we simulate regressions of a continuous dependent variable on two binary independent variables (HIGH and LABEL) as well as their interaction (HIGH x LABEL) for a set of different sample sizes. For each potential sample size and parochial bias, we repeat this exercise 500 times and report the proportion of times that the interaction term reaches statistical significance at the 5\%-level.

The results reported in Figure S.3 show that our study design, with more than 600 participants, has a statistical power of $80 \%$ and more to detect a parochial bias of $30 \%$ or more. This is equivalent to a standardized reduction of the MPCR effect size by less than $19 \%$ and implies that our experimental design can detect small or medium sized parochial biases at conventional levels of statistical significance (5\%) and power (80\%). In our setting, a parochial bias of 30\% corresponds to an absolute reduction of the MPCR effect size of 0.48. Alternatively, the power analysis for an interaction effect in a two-by-two between subject experiment can be based on a two-sided t-test of means with two independent samples (see Champely 2018) ${ }^{7}$ or a two-way ANOVA with two binary variables as well as their interaction on one continues dependent

\footnotetext{
${ }^{7}$ Champely S (2018), pwr: Basic Functions for Power Analysis. R package version 1.2-2. https://CRAN.Rproject.org/package=pwr
} 


\section{Figure S.3: Power calculations for parochial bias}

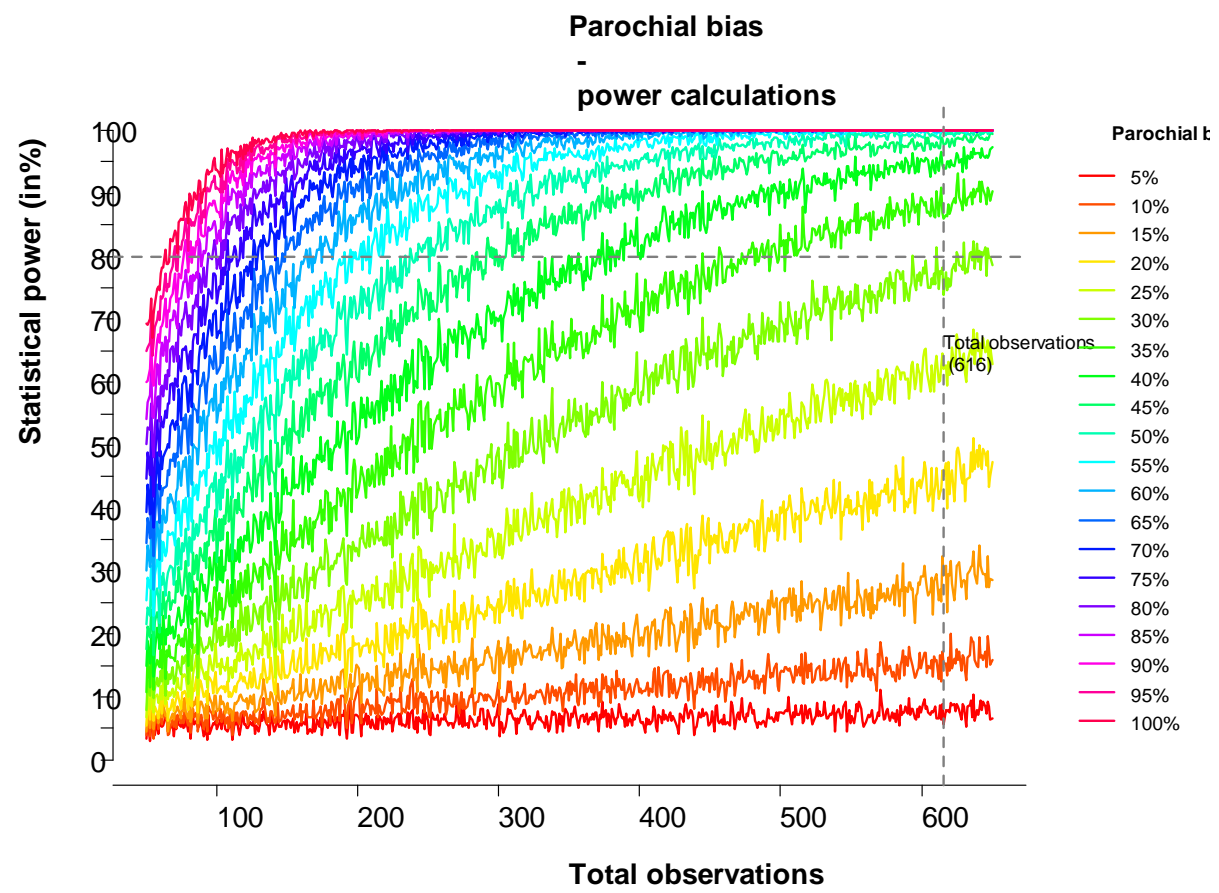

Note: Power curves for differently sized parochial biases between $5 \%$ and $100 \%$. Parochial biases are simulated as percentage reduction of the MPCR effect in LABEL compared to the MPCR effect in NOLABEL. Power calculations follow the procedure descripted by White $(2018)^{8}$ and are based on simulated regressions for combinations of different sample sizes and parochial biases.

variable (Qiu 2018) ${ }^{9}$. These alternative approaches confirm that our study design is adequate to detect a parochial bias of small or medium effect size at conventional levels of statistical significance and power.

8 White M (2018), Power two-way. GitHub repository. https://github.com/markhwhiteii/power_twoway

9 Qiu W (2018), powerMediation: Power/Sample Size Calculation for Mediation Analysis. R package version 0. 2.9. https://CRAN.R-project.org/package=powerMediation 